\title{
Conjoint analysis to evaluate consumer preference on certified agricultural products in the Central Taiwan
}

\author{
Rospita Odorlina P. Situmorang ${ }^{1}$, Bella P. Panjaitan ${ }^{2}$, Melchior Antoine ${ }^{2}$, and Chifumi \\ Takagi ${ }^{*}$ \\ ${ }^{1}$ Department of Forestry, National Chung Hsing University, 145 Xingda Rd., Taichung 40227, \\ Taiwan \\ 2 International Master Program of Agriculture, National Chung Hsing University, 145 Xingda Rd., \\ Taichung 40227, Taiwan
}

\begin{abstract}
Certified labels to verify the safety of agricultural products have gained the consumers' concerns in Taiwan. Therefore, conjoint analysis was conducted to investigate the effect of labels on consumer preferences by comparing three different logos and price levels. In addition, Pearson's correlation was used to determine how demographic factors affected food choice. The data collected from 83 respondents from two markets in Taichung City were carried out between December 16 and December 17, 2017. The study results showed that consumers chose agricultural products based on safety $(55.28 \%)$, as indicated by the product labeling compared to price $(44.72 \%)$. Of the three logos available, consumers preferred the first choice on the Traceable Agricultural Products (TAP) logo, followed by Certified Agricultural Standards (CAS) organic, CAS, and no logo. In terms of price, consumers preferred the middle price levels of NTD 50 and NTD 70 as simulated by $1 \mathrm{~kg}$ cabbage. Socioeconomic factors such as gender, education level, and the number of family dependents have no significant effect on the consumer choice of logos. However, health status, age, and income have a significant correlation with consumer preferences, which the poor health status, older, and wealthier costumers were more likely to purchase food with logo.
\end{abstract}

\section{Introduction}

Awareness of environment deterioration and food security has increased consumers' demand for certified environmentally and safe food products. Food certification is a method to ensure the safe and sustainable food through stipulating production practices with certain standards that have been practiced by countries [1,2]. It demonstrates that the suppliers comply with the certain standards provided by certification agencies which might be more convincing than if the supplier itself provided the assurance to buyers. Hence, the certification function is to allow consumers to know product information. It can include on what, how, and where the products were produced, which is beneficial to consumers to make choices.

\footnotetext{
*Corresponding author: takagi827@nchu.edu.tw
} 
Besides benefiting consumers, certification also helps producers such as farmers and suppliers through gaining premium prices, fair-trade verification, better access to global markets, and increasing the reputation of producers [3,4]. Certified products are more likely expensive than non-certified products because these products or materials are more difficult to work with, and they need specific and reengineering processes [5,6]. Sometimes, this specific processes augment additional costs of certified products as a return to invest sustainable practices [7]. Regarding fair trading, certification passes some acceptable production and trade standards, and the products are labeled with a certain logo or label making them easily distinguished from other products. It makes the certified food gain higher trust in the markets $[8,9]$. Through the operational standard, the certified products are also more easily accessed in the global level market.

A label or logo is a symbol given to products to distinguish them from others, which indicates that their compliance with certain standards has been verified or certified. A label is a form of communication of producers with consumers [1]. Labels can be differentiated into governmental logos and private organization logos [10]. However, consumers put higher trust in certified products with official logos released by the government $[6,11,12]$.

In Taiwan, labels refer to the certification of various agricultural and food products for food security released by the Agriculture Executive Yuan. Certification was first introduced on organic products in 1986. Later, the increasing consumer demand for food safety became a major consideration that encouraged the government to provide more safety measures on agricultural safeguarding. Considering this, the Council of Agriculture (COA) has introduced a number of food safety certifications, including the CAS, Good Agricultural Practices (GAP), Taiwan Agriculture and Food Traceability System (TAFTS), and the Agricultural Production and Certification Act in 2007 [13,14]. Another logo is the carbon label, which indicates the carbon footprint in certain products and is released by the Taiwan Environmental Protection Agency (TEPA) [9].

Quality and price are the two most decisive factors that influence the consumers' buying behavior $[12,15,16]$. When dealing with certified products, consumers stand for premium agricultural products $[5,17]$, and the consumers' willingness to buy certified products at higher prices is different for individuals [18]. The different logos and prices help consumers to select agricultural and food products. However, what factor that is most influential comparing logo and price is important to be evaluated to understand the criteria of food selection. Conjoint analysis (CA) is one of the measurement methods that can be used to examine consumer choice or preference by providing some criteria, such as different logos and prices [6,19-21]. For Taiwan, the research in determining the most preferred logo is important to be evaluated because Taiwan has a number of logos to certify food and agricultural products in markets. Previous studies that evaluated different food logos have been discussed in many countries, such as China, European countries and the USA $[10,12,22,23]$. In Taiwan, the studies on certified products and fair-trade certification have been conducted, such as for coffee and beans. However, those studies evaluated the imported certification labels such as USDA organic and UTZ certification [24]. It means that the studies that discuss and compare the different certified foods or logos locally Taiwan are still limited. To fill this research gap, this study intended to evaluate: (1) the customers' preferences for certified agricultural products based on different logos and price 
levels, and (2) the socioeconomic factors influencing the consumers' preferences for certified agricultural products.

\section{Methodology}

\subsection{Research approach and scopes}

This study used a quantitative approach through conjoint analysis to design the research and to analyze the data. The conjoint analysis approach is used to determine consumer preference for different logos and prices of certified products by doing an experimental exercise on product selection. In this research, we used cabbage as a product for experimental exercise. Three different logos (CAS, TAP, CAS Organic, and no logo) and four different price levels (NTD 30, 50, 70, and 90) were performed to evaluate the customers' preference. Then, the socioeconomic factors (gender, age, educational level, household sizes, income level, and health status) were analyzed to examine whether these factors influence the consumers' preferences for the different logos.

\subsection{Hypotheses development}

Increasing stakeholders' concern about food safety and food quality has encouraged the release of a large number of food labels or logos, including the release of local logos in Taiwan. Each logo has its specific purposes, which indicates the contents, and the process of production have different standards. Hence, it can be interpreted that consumers have different preferences on different labels $[6,10,12,23]$. A side from safety factors, price is a signal of product quality, which is also the main factor in determining product choice $[16,25,26]$. Scholars have also found that socioeconomic factors affect the willingness to buy certified products [5,6,26-28]. Hence, from the combination of different certification standards (quality), price, and social economic conditions of consumers, the hypotheses developed in this study were as follows:

H1: Consumer preferences for logos and different prices are not the same (different).

H2: Socioeconomic characteristics influence consumers' preferences for different logos of certified product logos.

\subsection{Data collection and sampling technique}

The data were gathered by an on-site survey method using a questionnaire, and the sampling method and sample number determination used a non-probability sampling method. A non-probabilistic sampling method is used when the population is unknown [29]. The samples were the consumers in two market centers, namely the Jian Kang Local Market, a traditional open-air market, and the NCHU Farmers' market, an organic farmers' market managed by NCHU. The two markets are in Taichung City, the central region of Taiwan. The respondents were randomly chosen and approached at both locations. At the end of the survey, we collected 43 questionnaires from the Jian Kang Local Marketand and 40 questionnaires from the NCHU Farmers' market. Hence, the total number of samples in this study was 83 consumers.

\subsection{Data analyzing}

The data of consumer preferences for the different logos and price levels were analyzed by conjoint analysis. Conjoint analysis is a preference elicitation method to identify the key 
attributes of selection through an experimental design by using the estimated preference structure to evaluate scenarios of interest. [30]. This method can be employed to evaluate various products, analyze respondents' evaluation of the products profiles, and draw inferences concerning preferences over attributes. The application of conjoint analysis, sometimes also referred to as a choice experiment, has become increasingly popular in studies on food marketing.

Table1.Attributes for Agriculture Product Logo

\begin{tabular}{|c|c|c|}
\hline Logo 1 (CAS) & Logo 2 (TAP) & Logo 3 (CAS-Organic) \\
\hline $\begin{array}{l}\text { CAS logo is a verification } \\
\text { benchmark to manage the } \\
\text { hygiene safety and quality } \\
\text { of raw materials, } \\
\text { processed, and final } \\
\text { agricultural products. }\end{array}$ & $\begin{array}{l}\text { TAP logo provides detailed } \\
\text { information of the crop from farm } \\
\text { to the retail store. Consumers can } \\
\text { search the crop information by } \\
\text { QR code on the TAP logo label. } \\
\text { TAP logo verifies a sustainable } \\
\text { agricultural production methods, } \\
\text { the safety production, and a } \\
\text { traceability of agricultural } \\
\text { products. }\end{array}$ & $\begin{array}{l}\text { CAS organic logo represents } \\
\text { that soil, water quality, use } \\
\text { of materials, post-harvest, } \\
\text { packaging, storage, and other } \\
\text { sectors in the crop } \\
\text { production process have } \\
\text { been checked by the certified } \\
\text { organic agency. }\end{array}$ \\
\hline
\end{tabular}

To perform CA in this study, we designed a simulation pattern using orthogonal design as presented in Table 2. It consists of four different logos (including no logo) and four different prices consisting of 16 card combinations. The information for each logo is presented in Table 1.

The consumers were asked to choose three cards as the most preferred combination. The cards for the first, second, and third choice were scored respectively by 4, 3, and 2 points, with the non-selected card being scored 1 . In a conjoint choice experiment, the assumption is that a respondent will choose combinations of profiles (in this study is logo and price) that give them maximum utilities. According to the random utility model, a respondent's utility can be calculated with the formula (1) used in Imami et al. study [31]

$$
U_{j}=V_{j}+e_{j}
$$

Where the $U_{j}$ represents the total utilities, $V_{j}$ is the systematic component of the utilities, and $e_{j}$ is a stochastic error. The equation to calculate the probability of respondents in class $\mathrm{t}$ to choose $\mathrm{j}$ is presented in formula (2). The population is divided into $t$ classes, $t=1,2, \ldots, \mathrm{T}$.

$$
P_{j . t}=\exp _{j . t} / \sum_{k \in A} \exp \left(V_{k . t}\right)
$$

After finishing the consumer preference analysis, the socioeconomic characteristics influencing the consumer choice were analyzed by the Pearson correlation. Both conjoint and Pearson correlation analyses were run using SPSS 23.0 software. 
Table 2. Simulation pattern on different logos and prices of cabbage selection

\begin{tabular}{|l|c|c|c|}
\hline & & \\
\hline
\end{tabular}

Note: 1 US\$ = 29 NTD (New Taiwan Dollar)

\section{Result and Discussion}

\subsection{Characteristics of respondents}

The characteristics of respondents are presented in Table 3. The respondents were dominated by female, aged between 45 to 53 years old, and completed a bachelor's degree. Most of the respondents have income level 20,999 NTD or below, which was quite low for Taiwan income level for workers, while a number of family dependents in the house mostly was about 3 and 4 people. Regarding the health status, most of them were in middle-level health status.

Table 3. Characteristics of the respondents

\begin{tabular}{|r|lr|r|r|}
\hline No. & Items & & Frequency & Percentage \\
\hline 1 & Gender & Male & 23 & 27.7 \\
& & Female & 60 & 72.3 \\
\hline 2 & Age & 24 years old or younger & 17 & 20.5 \\
& & $25-34$ years old & 12 & 14.5 \\
& & $25-44$ years old & 14 & 16.9 \\
& & $45-53$ years old & 29 & 34.9 \\
& & $55-64$ years old & 6 & 7.2 \\
& & 65 years old or older & 5 & 6.0 \\
\hline
\end{tabular}




\begin{tabular}{|c|c|c|c|c|}
\hline 3 & Educational level & $\begin{array}{c}\text { Not complete high school } \\
\text { High school } \\
\text { Bachelor degree } \\
\text { Master degree } \\
\text { Doctoral degree }\end{array}$ & $\begin{array}{r}11 \\
20 \\
43 \\
8 \\
1\end{array}$ & $\begin{array}{r}13.3 \\
24.1 \\
51.8 \\
9.6 \\
1.2\end{array}$ \\
\hline 4 & Marital status & $\begin{array}{c}\text { Single } \\
\text { Married with no child } \\
\text { Married with child/children } \\
\text { Married, child/children grown adult } \\
\text { No will to mention }\end{array}$ & $\begin{array}{r}27 \\
4 \\
15 \\
36 \\
2\end{array}$ & $\begin{array}{r}32.1 \\
4.8 \\
17.9 \\
42.9 \\
2.4\end{array}$ \\
\hline 5 & $\begin{array}{l}\text { Number of people } \\
\text { in the household }\end{array}$ & $\begin{array}{c}\text { 1-2 people } \\
3-4 \text { people } \\
5-6 \text { people } \\
7 \text { people or more }\end{array}$ & $\begin{array}{r}7 \\
48 \\
24 \\
4\end{array}$ & $\begin{array}{r}8.4 \\
57.8 \\
28.9 \\
4.8\end{array}$ \\
\hline 6 & Profession & $\begin{array}{l}\text { Housewife/househusband } \\
\text { Government officer } \\
\text { Private sector } \\
\text { Entrepreneur } \\
\text { Others } \\
\end{array}$ & $\begin{array}{r}19 \\
7 \\
11 \\
7 \\
39 \\
\end{array}$ & $\begin{array}{r}22.9 \\
8.4 \\
13.3 \\
8.4 \\
47.0\end{array}$ \\
\hline 7 & Level of income & $\begin{array}{c}\text { >NT 20,999 } \\
\text { NT21,000-NT30,999 } \\
\text { NT31,000-NT40,999 } \\
\text { NT41,000-NT50,999 } \\
\text { NT51,000-NT60,999 } \\
\text { NT61,000 or higher } \\
\end{array}$ & $\begin{array}{r}27 \\
14 \\
13 \\
9 \\
6 \\
14\end{array}$ & $\begin{array}{r}32.5 \\
16.9 \\
15.7 \\
10.8 \\
7.2 \\
16.9\end{array}$ \\
\hline 8 & Health status & $\begin{array}{c}\text { Poor } \\
\text { Moderate } \\
\text { Excellent }\end{array}$ & $\begin{array}{r}5 \\
66 \\
12\end{array}$ & $\begin{array}{r}6.0 \\
79.5 \\
14.5\end{array}$ \\
\hline
\end{tabular}

\subsection{Consumers' preferences on different logos and prices}

Taichung City, located in central Taiwan, is the second biggest city in Taiwan. Taichung consumers, represented by $72.69 \%$ of the total sample, clearly understood the TAP, CAS, and CAS organic logos. While $27.31 \%$ of them were partially familiar with the three logos and they have ever seen the three logos. Furthermore, we continued to evaluate the consumer preference by providing 16 possible combinations of logos and prices as represented by the cards that available in Table 2 . The consumers had to select three options they preferred the most and rank them in order of importance. The rank of each logo and price, and the average score of each combination card can be seen in Table 4.

As it can be seen from Table 4, the most preferred combination is the card number 1 that is the TAP logo with the price NTD 50. Next, it is followed by the organic logo with the price NTD 50 (Card 12), and the organic logo with price NTD 70 (Card 16). To describe the significance of each treatment group and to prove the hypothesis, the analysis was continued with ANOVA testing as presented in Table 5. 
Table 4. The card combination and average score of cards obtained from 83 respondents

\begin{tabular}{|l|l|r|r|r|r|r|r|r|r|}
\hline $\begin{array}{l}\text { Card } \\
\#\end{array}$ & $\begin{array}{l}\text { CAS } \\
\text { Organic/ } \\
\text { Nonorganic }\end{array}$ & $\begin{array}{l}\text { TAP/ } \\
\text { No TAP }\end{array}$ & $\begin{array}{l}\text { CAS/ } \\
\text { No } \\
\text { CAS }\end{array}$ & $\begin{array}{l}\text { No } \\
\text { logo/ } \\
\text { Or } \\
\text { not }\end{array}$ & $\begin{array}{l}\text { NTD } \\
\mathbf{3 0} / \mathbf{n o}\end{array}$ & $\begin{array}{l}\text { NTD } \\
\mathbf{5 0} / \\
\text { No 50 }\end{array}$ & $\begin{array}{l}\text { NTD } \\
\text { 70/ } \\
\text { No 70 }\end{array}$ & $\begin{array}{l}\text { NTD } \\
\mathbf{9 0} / \\
\text { No 90 }\end{array}$ & $\begin{array}{l}\text { Average } \\
\text { score }\end{array}$ \\
\hline 1 & 0 & 1 & 0 & 0 & 0 & 1 & 0 & 0 & $\mathbf{1 . 9 8}$ \\
\hline 2 & 0 & 0 & 0 & 1 & 1 & 0 & 0 & 0 & 1.30 \\
\hline 3 & 0 & 0 & 1 & 0 & 0 & 0 & 0 & 1 & 1.33 \\
\hline 4 & 0 & 1 & 0 & 0 & 0 & 0 & 1 & 0 & 1.47 \\
\hline 5 & 0 & 0 & 1 & 0 & 0 & 0 & 1 & 0 & 1.41 \\
\hline 6 & 0 & 0 & 0 & 1 & 0 & 1 & 0 & 0 & 1.05 \\
\hline 7 & 0 & 0 & 1 & 0 & 1 & 0 & 0 & 0 & 1.25 \\
\hline 8 & 1 & 0 & 0 & 0 & 1 & 0 & 0 & 0 & 1.47 \\
\hline 9 & 0 & 0 & 1 & 0 & 0 & 1 & 0 & 0 & 1.55 \\
\hline 10 & 0 & 1 & 0 & 0 & 1 & 0 & 0 & 0 & 1.41 \\
\hline 11 & 0 & 0 & 0 & 1 & 0 & 0 & 0 & 1 & 1.05 \\
\hline 12 & 1 & 0 & 0 & 0 & 0 & 1 & 0 & 0 & $\mathbf{1 . 6 4}$ \\
\hline 13 & 1 & 0 & 0 & 0 & 0 & 0 & 0 & 1 & 1.31 \\
\hline 14 & 0 & 0 & 0 & 1 & 0 & 0 & 1 & 0 & 1.02 \\
\hline 15 & 0 & 1 & 0 & 0 & 0 & 0 & 0 & 1 & 1.20 \\
\hline 16 & 1 & 0 & 0 & 0 & 0 & 0 & 1 & 0 & $\mathbf{1 . 5 5}$ \\
\hline
\end{tabular}

Table 5. ANOVA Analysis

\begin{tabular}{|l|c|c|c|c|c|}
\hline & df & SS & MS & F & Significance F \\
\hline Regression & 6 & 0.649 & 0.108 & 3.762 & 0.037 \\
\hline Residual & 9 & 0.259 & 0.029 & & \\
\hline Total & 15 & 0.907 & & & \\
\hline
\end{tabular}

The one-way ANOVA shows a statistically significant difference between labels and prices $(\mathrm{F}(6,9)=3.762, p=0.037)$. or the $F$-value $(0.037)$ is smaller than $0.05\left(\mathrm{H}_{1}\right.$ is accepted). It means that consumer preference varies and significantly among the various logos and prices. In the other words, it can be said that the different functions of labels and prices are still a consideration to consumers when making the purchase decisions. This finding is consistent with the previous study, which found that consumers hold different preferences on different labels $[6,23]$ and prices $[15,16]$. Furthermore, statistical regression analysis of the treatment group can be seen in Table 6 .

Table 6. Regression statistic

\begin{tabular}{|l|l|}
\hline Regression statistics & Values \\
\hline Multiple R & 0.846 \\
\hline R Square & 0.7149 \\
\hline Adjusted R Square & 0.525 \\
\hline Standard Error & 0.170 \\
\hline Observations & 16 \\
\hline
\end{tabular}


Table 6 shows that $\mathrm{R}$ square value is 0.7149 . $\mathrm{R}$ square is also called the determinant coefficient. R square value presents between $0-1$. The determinant coefficient of the survey on food logo and price is $71.49 \%$ indicating that $71.49 \%$ of the decision to purchase the agricultural products is determined by the presence of logo and price. Furthermore, to determine which part of the two variables (logo and price) has the greater effect to consumers when purchasing the labeled foods, the following analysis was the determination of Partial Utility Value (PUV).

\section{PUV $=$ coefficient - average of logo \& price coefficient}

The calculations are presented in Tables 7 and 8.

Table 7. Coefficient values of the logo and price group combinations

\begin{tabular}{|l|r|r|r|r|r|r|r|r|}
\hline & Coefficients & $\begin{array}{c}\text { Standard } \\
\text { Error }\end{array}$ & t-Stat & p-value & $\begin{array}{c}\text { Lower } \\
\mathbf{9 5 \%}\end{array}$ & $\begin{array}{c}\text { Upper } \\
\mathbf{9 5 \%}\end{array}$ & $\begin{array}{c}\text { Lower } \\
\mathbf{9 5 . 0 \%}\end{array}$ & $\begin{array}{c}\text { Upper } \\
\mathbf{9 5 . 0 \%}\end{array}$ \\
\hline Intercept & 1.089 & 0.112 & 9.710 & 0.000 & 0.835 & 1.343 & 0.835 & 1.343 \\
\hline $\begin{array}{l}\text { Organic/non- } \\
\text { Organic }\end{array}$ & 0.389 & 0.120 & 3.241 & 0.010 & 0.117 & 0.660 & 0.117 & 0.660 \\
\hline TAP/no TAP & 0.410 & 0.120 & 3.417 & 0.008 & 0.138 & 0.681 & 0.138 & 0.681 \\
\hline $\begin{array}{l}\text { CAS/no } \\
\text { CAS }\end{array}$ & 0.280 & 0.120 & 2.337 & 0.044 & 0.009 & 0.551 & 0.0090 & 0.551 \\
\hline NT50/no 50 & 0.196 & 0.120 & 1.633 & 0.137 & -0.075 & 0.467 & -0.075 & 0.467 \\
\hline NT70/no 70 & 0.006 & 0.120 & 0.050 & 0.961 & -0.265 & 0.277 & -0.265 & 0.277 \\
\hline \begin{tabular}{l} 
NT90/no 90 \\
\hline
\end{tabular} & -0.136 & 0.120 & 1.131 & 0.288 & -0.407 & 0.136 & -0.407 & 0.136 \\
\hline
\end{tabular}

Table 8. Partial Utility Value (PUV)

\begin{tabular}{|c|c|c|c|c|c|c|}
\hline Attributes & Level & Coefficient & $\begin{array}{c}\text { AVERAGE } \\
\text { COEF }\end{array}$ & PUV & $\begin{array}{c}\text { Range } \\
\text { of } \\
\text { PUV } \\
\end{array}$ & $\begin{array}{c}\text { Importance } \\
(\%)\end{array}$ \\
\hline \multirow[t]{4}{*}{ LOGO } & Organic & 0.389 & 0.270 & 0.118 & \multirow[t]{4}{*}{0.410} & \multirow[t]{4}{*}{55.28} \\
\hline & TAP & 0.410 & & 0.140 & & \\
\hline & CAS & 0.280 & & 0.011 & & \\
\hline & $\begin{array}{l}\text { No } \\
\text { Logo }\end{array}$ & 0 & & -0.270 & & \\
\hline \multirow[t]{4}{*}{ PRICE } & NT 30 & 0 & 0.017 & -0.017 & \multirow[t]{4}{*}{0.331} & \multirow[t]{4}{*}{44.72} \\
\hline & NT 50 & 0.196 & & 0.179 & & \\
\hline & NT 70 & 0.006 & & -0.011 & & \\
\hline & NT 90 & -0.136 & & -0.152 & & \\
\hline
\end{tabular}

From the PUV value in Table 8, the logo referring to qualified food more affect the consumers' decision $\mathbf{( 5 5 . 2 8 \% )}$ in purchasing food product than the price $\mathbf{( 4 4 . 7 2 \% )}$. This finding confirms that consumers prioritize quality more than price, which has also been indicated by previous scholars $[6,15,32]$. Regarding certified labeled food, quality can reflect food safety, which includes hygiene safety, quality of raw materials and final 
products, and production process [33-36]. Furthermore, the result of Table 8 shows that among the three logos, the TAP logo is the most preferred with the Coefficient value of 0.410 , continued by CAS organic 0.389 , and CAS 0.2801 . The comparison of the coefficient and PUV is presented in Figure 1.

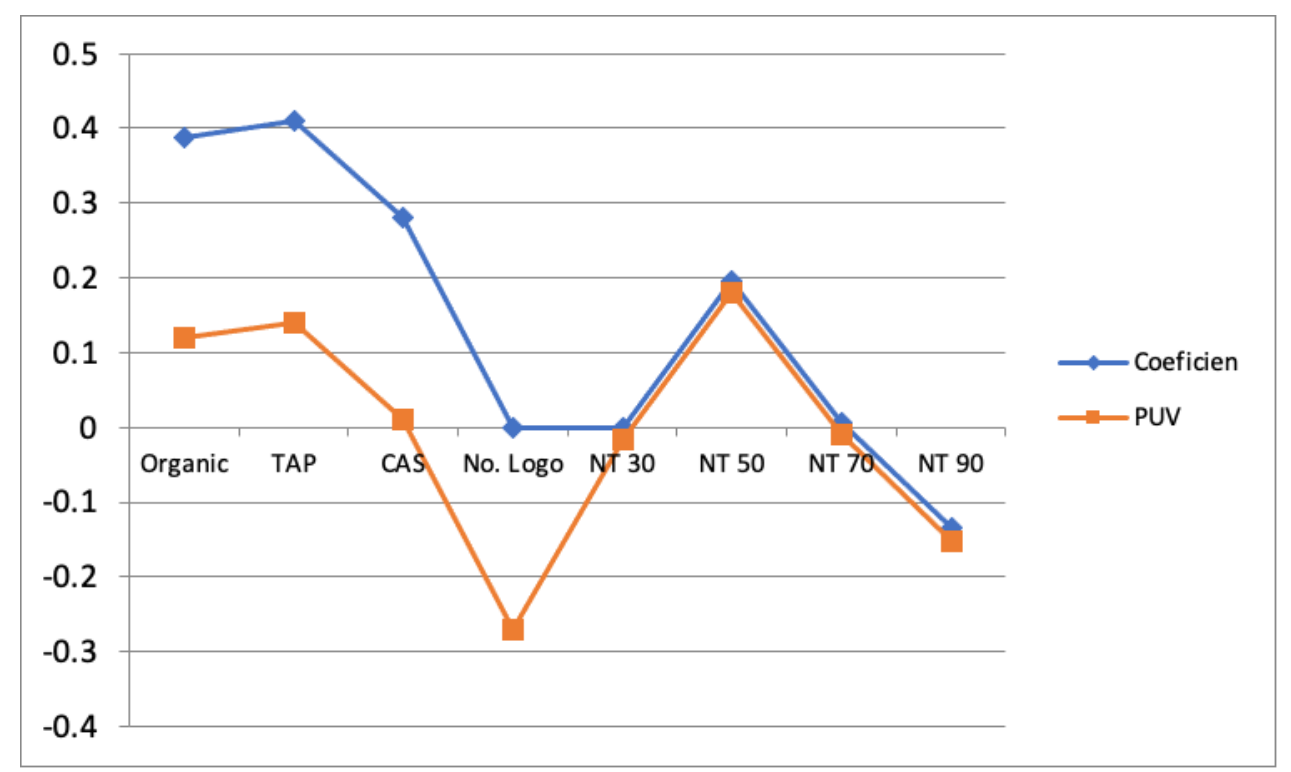

Fig1. Comparison of coefficient and PUV for different logos and prices.

Following the description of TAP, CAS and CAS organic logos in Table 1, the number of standard criteria of the three logos are the same to each other for the hygiene, safety, and GAP criteria. However, the TAP logo has traceability criterion and CAS organic possesses all organic material and processing criteria. The TAP logo provides QR code in the packages of agricultural products that make them ease to trace by consumers. The provision of QR code can help consumers to find information of the detailed information of the crop from farm to retail store level. It might be the influencing factor of the highest consumers' preference for TAP compared to the other two labels. Liu et al. [1] stated that a label is a form of communication with consumers. Hence, traceability of certified products, such as the provision of barcodes or QR codes, will increase customer trust worthiness of the certification process[11].This finding is also supported by Huang and Lee [37], who found that the more information received from the certification of products, the more consumers will perceive the products. Moreover, the similarity of the design logo of CAS and CAS organic is assumed to cause consumer confusion in terms of differentiating the two logos, as indicated by Comas et al. [38] and Yang et al. [39].The similarities of CAS and CAS organic logo have received Taiwan government attention, that in 2019, the government released a different logo for organic products [40].

Regarding price, the products with the middle price of $1 \mathrm{~kg}$ labeled and non-labeled cabbages were chosen as the first choice (NTD 50 followed by NTD 70). While for the 
lowest price (NTD 30), they assumed that it was too low for a certified cabbage, and for NTD 90 prices, this price is too high. From this finding, it can be said that consumers will choose the lower price for certified products with the standard criteria on safety food is still acceptable. Hence in the CA simulation, the choice falls on the medium price that still meets the food safety criteria in the eyes of consumers. A study conducted by Ortega et al. [11] also mentioned that price negatively influences the willingness to buy certified products, which means that consumers intend to buy cheap products. However, high quality and safe food premium prices guaranteed by certification are also important. The middle price of cabbage seems to be the meeting point of buying ability and food quality preferred by most of the consumers. This result is different from the Krystallis and Ness [6] study, which found the highest price of organic olive oil product was the most preferred combination by consumers.

\subsection{The correlation between different socioeconomic characteristics and certified agricultural product}

By calculating the total score of each logo, the correlation between the socioeconomic characteristics of the respondents and three logos and no logo was analysed by Pearson correlation and the result can be seen in Table 9.

Table 9. Pearson correlation of socioeconomic characteristics with different logos.

\begin{tabular}{|l|r|r|r|r|}
\hline \multicolumn{1}{|c|}{$\begin{array}{c}\text { Respondent } \\
\text { Characteristics }\end{array}$} & \multicolumn{1}{c|}{ TAP } & CAS-Organic & \multicolumn{1}{c|}{ CAS } & \multicolumn{1}{c|}{ No Logo } \\
\hline Gender & -.075 & .133 & -.030 & -.103 \\
\hline Age & -.043 & .148 & -.008 & $-.231\left(^{*}\right)$ \\
\hline Education & .149 & .030 & -.115 & -.167 \\
\hline $\begin{array}{l}\text { People in } \\
\text { household }\end{array}$ & .026 & -.049 & .043 & -.011 \\
\hline Income & .045 & .191 & -.171 & $-.234\left(^{*}\right)$ \\
\hline Health Status & .058 & -.210 & $-.277\left(^{*}\right)$ & -.092 \\
\hline
\end{tabular}

* Correlation is significant at the 0.05 level (2-tailed), $\mathrm{N}=83$

Based on the results in Table 9, in general, the socioeconomic characteristics had no significant correlation with the decision to choose any product with a particular logo, except the CAS logo and no logo. For the CAS logo, health status significantly negatively influences the preference for the CAS logo, where the excellent health status less prefers the CAS logo compared to the poorer health condition. It is acceptable because people with poor health conditions have concerns about food quality and safety to improve their health, which can be fulfilled by certified products. The similar result was also found by Botonaki et al. [33], who mentioned that people who placed importance on health prefer certified foods. Likewise, for cabbage with no logo, age level, and income level have a significant negative correlation with food without logo. This result can indicate that people of younger age prefer less on certified food. Connected to the above discussion on health status, younger people usually have better health conditions, and they care less about food taking or are more sceptical about certified products [26]. It is also in line with income, where the 
consumers with lower income prefer the non-labeled foods, or vice versa, the people with higher income levels prefer the certified labeled products [26]. The price is the reason for these two results. The younger people and the lower income level less prefer certified cabbage because the certified cabbage with labels is more expensive compared to the nonlabeled foods.

Other demographic backgrounds, such as gender, educational level, and the number of dependents in the households, do not show a significant correlation with foods with labels. In contrast, other studies have shown significant correlations between gender, education, and number of dependents on willingness to buy certified food products[5,6,26,28,41,42]. This result indicates that consumers in Taichung are already familiar enough with the logo to the extent that these demographic distributions do not significantly affect the choice. In addition, the limited sample number interviewed in the research could have been increased to obtain a better demographic presentation. More varied types of markets can also be investigated to get more details of demographics, and how they affect product choices.

\section{Conclusion}

Trends in the growth of certified foods reflect producers seeking alternatives to past production practices and attempting to achieve new ways to differentiate their products. Similarly, in Taiwan, certified products with specific advantages and security are offered to consumers. The release of three kinds of logos (TAP, CAS, and Organic) by Taiwan Government indicating the security level of food gradually also affects consumer in purchase decisions. CAS, TAP, and CAS organic logos that have different standards of verified criteria of agricultural products and different prices had been simulated to understand the consumers preference when purchase agricultural products. This study yielded that consumer prefer to choose foods with logos that indicate higher quality and safety, as opposed to relying on price. In terms of price, consumers prefer the middle price level. That means that economic ability or income levels limit the desire to purchase highprice products indicated by a higher quality logo. Among the logos, consumers preferred the TAP logo the most that have fulfilled the hygiene, safety, GAP, and traceability criteria, followed by CAS organic, CAS, and no logo. Demographic factors such as gender, level of education, number of family dependents, and health status do not have a significant impact on consumers' choice of logo. However, health status, age, and income have a significant correlation with certified labeled products. From the results, Taiwanese are sufficiently familiar with the logos (certified products) so that these demographic factors do not affect their purchasing decisions in a significant way. Nonetheless, it can still be seen that the poorer health, older, and wealthier customers prefer purchasing food of higher quality by the various logo. 


\section{References}

1. P. Liu, M. Andersen, C. Pazderka. Voluntary Standards and Certification for Environmentally and Socially Responsible Agricultural Production and Trade (FAO the UN, Rome, 2004)

2. Y. Onozaka, D.T. Mc. Fadden. American J. Agri. Econ., 93, 689-702 (2011)

3. M. A. Delmas, L. E. Grant. Business \& Society, 53, 6-44. (2010).

4. E. Latynskiy, T. Berger. J. Agri. Econ., 68, 727-748 (2016).

5. B. Chekima, S. A. W. S. K. Wafa, O. A. Igau, S. Chekima, S. L. Sondoh Jr. J. Cleaner Prod., 112, 3436-3450. (2016)

6. A. Krystallis, M. Ness. Int. Food Agribusiness Manag. Rev., 8, 62-91 (2005)

7. C. A. Roheim, F. Asche, J. I. Santos. J. Agri. Econ., 62, 655-668 (2011)

8. L. T. Raynolds. Agri. Human Values, 31(3), 499-511 (2014)

9. T. C. Liang, R. O. P. Situmorang, M. C. Liao, S. C. Chang. Sustainability, 12, 7892 (2020)

10. M. Janssen, U. Hamm. Food Quality and Preference, 25, 9-22 (2012)

11. D. L. Ortega, H. H. Wang, L. Wu, N. J. Olynk. Food Policy, 36, 318-324 (2011).

12. C.N. Anastasiou, K.M. Keramitsoglou, N. Kalogeras, M.I. Tsagkaraki, I. Kalatzi, and K.P. Tsagarakis. Sustainability, 9, 1-17 (2017)

13. Council of Agriculture (COA) of ROC. Council of Agriculture, Executive Yuan of Republic of China. Accessed from https://eng.coa.gov.tw/theme_list.php?theme=eng_topics\&issue $=71$ access at 1 June 2021]

14. Legislative Council Secretariat of ROC. (2014). Available in http://www.legco.gov.hk/research-publications/english/1314in16-taiwans-agriculturalpolicy-20140703-e.pdf [access at 8 June 2021]

15. A. Dapkevičius and B. Melnikas. Science - Future of Lithuania, 1, 17-20. (2009).

16. M.J. Osei, D. R. Lawer, R. Aidoo. Asian J. Agri. Rural Develop., 2, 351-365 (2012)

17. L. Wang, X. Huo. Food Control, 64, 240-246 (2016)

18. A. Lappo, T. Bjørndal, J.F. Polanco, A. Lem. Food Markets. FAO (Fisheries and Aquaculture Circular, FAO of The UN, Rome, 2015)

19. R. Harrison, A. Ozayan, S. P. J. Agri. Appli. Econ., 30, 257-265. (1998)

20. M. Van Der Pol, M. Ryan. British Food J., 98, 5-12 (1996)

21. H. Saito, Y. Saito. Agribusiness, 29, 147-161 (2013)

22. D. Moscovici, R. Rezwanul, R. Mihailescu, J. Gow, A. A. Ugaglia, L. Valenzuela, A. Rinaldi. Int. J. Wine Business Res. 33, 153-175 (2020).

23. J. Wang, J. Tao, M. Chu. Food Control, 108, 106825 (2020)

24. C. C. Liu, C. W. Chen, H. S. Chen. Sustainability, 11, 1297 (2019)

25. G. Mastrobuoni, F. Peracchi, A. Tetenov. J. Wine Econ., 9, 135-152 (2014)

26. L. Witek, W. Kuźniar. Sustainability, 13, 209 (2021)

27. V. Bilotkach. Bulletin of Economic Research, 66, 231-245. (2014)

28. K. G. Grunert, S. Hieke, J. Wills. Food Policy, 44, 177-189. (2014)

29. D. Aaker, V. Kumar, and G. Day. Marketing research. 800 (John Wiley and Sons, New York, 2003)

30. D. Hensher, J. Louviere, J. Swait. J. Econometrics 89,197-221. (2000)

31. D. Imami, C.Chan-Halbrendt, Q.Zhang, E.Zhllima. Int. Food and Agri. Manag. Rev.14,111-126(2011).

32. A. Biswas,J. Advanced Manag. Sci., 4, 211-215 (2016)

33. A. Botonaki, K. Polymeros, E. Tsakiridou, K. Mattas. British Food J.,108 (2), 77-90. (2006) 
34. E. Horska, J. Ürgeová, R. Prokeinova. Agri. Econ., 57(10), 493-499. (2011)

35. D. P. Kafetzopoulos, K. D. Gotzamani. Food control, 40, 1-11. (2014)

36. S. H. Yang, B. P. Panjaitan, K. Ujiie, J. W. Wann, D. Chen. Food Quality and Preference, 87, 104042 (2021)

37. C.H. Huang, C.H. Lee. China Agri. Econ. Rev., 6,198-211. (2014)

38. Comas, J.M. Marti,R.W. Seifert. Accessed from http://www.imd.org/news/Ecolabelsstudy.cfm [access at 8 June 2021]

39. A. P. Yang, S.C. Chang, T.C. Liang, R.O.P. Situmorang, M. Hussain. Sustainability, 13(4), 1606. (2021).

40. Taiwan Organic Information Portal. Accessed from https://info.organic.org.tw/6003/ [access at 8 June 2021]

41. A. Grubor, N. Djovic. British Food J., 118, 164-182. (2016)

42. K. Darby, M. T. Batte, S. Ernst, B. Roe.American J. Agri.Econ.,90, 476-486. (2008) 